\title{
Optimal Model of Investment Decision for Distribution Network Construction Project
}

\author{
$Y U$ Haozheng ${ }^{1}$, SUN Huijun ${ }^{2}, L I \mathrm{Ke}^{1}$, ZHOU Peng ${ }^{3}, G U O$ Xinzhi ${ }^{1}, P A N$ Zhaolun $^{2}, Y U$ Jinxiong $^{2}$, WANG Kehui ${ }^{2}$ \\ and $L I \mathrm{Yulu}^{2}$ \\ ${ }^{1}$ State Grid Henan Electric Power Company Economic and Technology Research Institute, Zhengzhou 450000, Henan Province \\ ${ }^{2}$ North China Electric Power University, Changping District 102206, Beijing; \\ ${ }^{3}$ State Grid Henan Electric Power Company, Zhengzhou 450000, Henan Province
}

\begin{abstract}
In order to meet the requirements of precise investment in the distribution network under the new power reform, this paper proposes an optimization model for the investment decision of the distribution network. With the largest net present value rate and the smallest comprehensive cost of grid operation as the optimization goal, and certain capital constraints as constraints, a distribution network 0-1 programming model is established and solved by LINGO software; the analysis of an example shows that this model can ensure the safety of investment in the distribution network and the precise investment allocation in the distribution network under certain financial constraints.
\end{abstract}

\section{Introduction}

In the context of the in-depth promotion of the new power reform, the power grid pays more attention to the lean management of investment. As the core part of the power system, the distribution network proposes a scientific and comprehensive distribution network investment decision-making optimization method, which is the key to effectively improving the level of power grid investment management.

The investment optimization of distribution network construction projects is currently a hot research topic. Literature [11] chooses to take the maximum annual expected benefit investment ratio of the distribution network as the objective function, comprehensive investment capital constraints, load demand constraints, and financial benefits. This is an optimization method for annual investment decision-making based on the largest annual return; literature [13] uses an improved TOPSIS method to make investment optimization decisions on the established set of distribution network benefit evaluation index system. References [14] and [15] analyzed the sensitivity of individual projects to comprehensive indicators and obtained optimal results within a certain project investment limit. In the past, scholars paid more attention to the investment benefits brought by the investment of distribution network projects, but often ignored the urgency of investment in the construction of distribution network projects, and it was difficult to achieve the "precision" goal of investment.

This paper proposes a decision-making optimization model for distribution network construction projects. A 0-1 linear programming optimization model is constructed based on the objective functions such as the largest net present value rate and the smallest comprehensive cost of grid operation, as well as the investment ratio and other constraints, and the calculation and analysis are given to obtain investment results and optimize resource allocation.

\section{Optimal Model of Investment Decision for Distribution Network Project}

In order to solve the optimization problem of the investment decision-making of the distribution network project, a 0-1 programming model is established to make the optimization decision of the project, mainly to analyze the objective function, constraint conditions and model solution method of the matching algorithm of the investment project and the different types of investment urgency of the distribution network .

Since power grid investment is a physical investment project, the total investment is fixed, and the investment amount of each project is also fixed, so the decision result should not be the proportion of investment but should be whether to invest in the project. General linear programming cannot solve the fixed cost problem, so 0-1 linear programming is needed. In order to determine whether a project is adopted or eliminated, an optimized variable $0-1$ vector $X$ can be defined.

$$
X=\left[x_{1}, x_{2} \ldots x_{i} \ldots x_{n}\right]
$$

In the formula, $x_{i}$ represents the selection of the $\mathrm{i}$-th item, $x_{i}$ is a variable, and only takes 0 or 1 . When it is 0 , it means that the item is not selected, and when it is 1 , it means that the item is selected; $\mathrm{n}$ is the total number of alternative items.

\footnotetext{
* Corresponding author: m15295931235@163.com
} 


\subsection{Objective function}

(1) Optimal objective function of investment decision for distribution network project

In order to measure the power grid's ability to respond to risks with increased investment, first consider the security benefits of the grid, while focusing on economic benefits, and select the operation of the grid (the minimum overall cost and the largest net present value rate) as the objective function.

Objective function 1: Minimal overall cost of grid operation

Grid operation requires comprehensive consideration of its reliability and economy. To pursue high reliability, generally more backup costs must be invested to avoid the risk of power outage. If the pursuit of low backup cost is ignorant, it may result in low reliability of grid operation and power outages. The risk is very high, which will bring greater risk loss. Therefore, the operation of the power grid should balance the reliability cost and the risk cost of power outage. As shown in Figure 1, find the intersection of reliability cost and power outage risk cost (comprehensive cost) as the best advantage of grid operating costs. It can be calculated as follows:

$$
\left\{\begin{array}{l}
C_{\text {risk }}=F(t) \\
C_{\text {spare }}=F(m)
\end{array}\right.
$$

In the formula, $C_{\text {risk }}$ is the comprehensive risk cost of power grid operation; $F(t)$ is the cost function of power grid outage risk; $C_{\text {spare }}$ is the economic loss cost of power grid outage; ${ }^{F(m)}$ is the power grid reliability cost function; when $C_{\text {risk }}=C_{\text {spare }}$, the obtained value is $C_{j o \text { int }}$, which is the power grid The minimum overall operating cost.

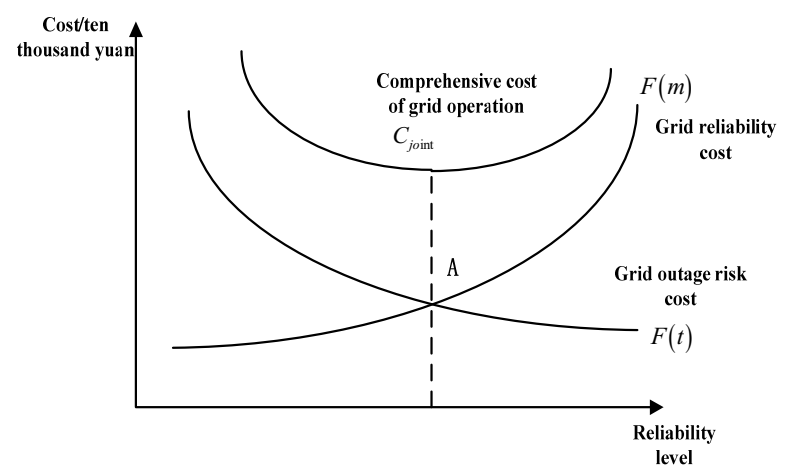

Fig. 1. Reliability Cost-Grid Outage Risk Cost Analysis Curve

Objective function 2: Maximum net present value rate

Net present value refers to the sum of the present value of discounting the net cash flow of each year during the project calculation period to the beginning of the construction period according to the industry benchmark rate of return or the set discount rate. Net Present Value Rate (NPVR, Net Present Value Rate), also known as net present value ratio and net present value index, refers to the ratio of the project' $s$ net present value to the original investment present value, also known as the "total net present value". The net present value rate is a dynamic investment income indicator, used to measure the profitability of different investment schemes, and to indicate the size of the net present value that can be achieved by the present value of a project's unit investment. The net present value rate is small, the return of unit investment is low, and the net present value rate is large, the return of unit investment is high. The net present value formula can be defined as follows:

$$
N P V=\sum_{t=0}^{n}(C I-C O)_{t}\left(1+i_{0}\right)^{-t}
$$

In the formula, $N P V$ is the net present value, $C I t$ is the cash inflow in year t, $\mathrm{COt}$ is the cash outflow in year $t, n$ is the life of the project, and $i_{0}$ is the benchmark discount rate. The net present value can be calculated according to the financial cash flow statement. Projects with a net present value $\geqslant 0$ are financially acceptable. In the multi-plan comparison, the one with the largest financial net present value is the best.

The following formula is the net present value rate formula:

$$
N P V R=\frac{N P V}{I_{\mathrm{p}}} \times 100 \%
$$

In the formula, $N P V R$ is the net present value rate, $N P V$ is the net present value, and $I_{\mathrm{p}}$ is the present value of the project's original investment.

Therefore, in order to match the selected project with the weak links of the grid operation as a whole, to minimize the comprehensive cost of the selected project to the grid operation and maximize the net present value rate, the objective function is constructed as shown in Equations (5) and (6).

$$
\begin{aligned}
& \min C_{j o \text { int }}=\sum_{i=1}^{n}\left(C_{j o \text { int }-i} \times x_{i}\right) \\
& \max N P V R=\sum_{i=1}^{n}\left(N P V R_{i} \times x_{i}\right)
\end{aligned}
$$

In the formula, ${ }^{C}{ }_{j o \text { int }}$ and $N P V R$ are the decision value of the project, ${ }^{C}{ }_{j o \text { int }-i}$ is the comprehensive cost value of the $i$-th project on the grid operation; $N P V R_{i}$ is the net present value rate of the $i$-th project, and $n$ is the total number of projects included in the project.

\subsection{Restrictions}

For investment projects matching the algorithm for the urgency of power grid investment, the constraints mainly include the total investment constraint, the investment allocation ratio constraint, and the relationship between projects.

(1)Total investment constraints

The total investment constraint can be expressed as follows:

$$
\sum_{j=1}^{P_{n}}\left(c_{P_{\mathrm{j}}} \times x_{P_{\mathrm{j}}}\right) \leq T_{\mathrm{P}}
$$


In the formula, $c_{i}$ represents the planned investment of the $i$-th project, and $T$ represents the total investment in the grid this year.

(2)Investment allocation ratio constraint

First of all, according to the relationship between the growth of the historical operating characteristics of the power grid in the region and the amount of investment, and the content of the investigation, the contribution of different types of projects to the development of the power grid can be determined, and the investment proportions can be allocated according to the project types.

For category a and $\mathrm{b}$ projects classified according to investment decision attributes, the investment allocation ratio constraint can be expressed as follows:

$$
\sum_{j=1}^{P_{n}}\left(c_{P_{\mathrm{j}}} \times x_{P_{\mathrm{j}}}\right) \leq T_{\mathrm{P}}
$$

In the formula, $C p_{j}$ represents the planned investment amount of the $j$-th project under the category $P$ project, $P n$ represents the total number of projects in the category $P$ project, $T p$ represents the total investment of the category $P$ project, and $P$ is equal to a or b.

(3)Relational constraints between projects

1) Mutually Exclusive Project. If item i and item k are mutually exclusive and can only choose one of them, the constraint equation can be expressed as $x_{i}+x_{j} \leq 1$

2) Dependent Project. If there are item $\mathrm{k}$ and item 1 , and the occurrence of item $\mathrm{k}$ must be established when item 1 occurs, the constraint equation can be expressed as $x_{k}-x_{l} \leq 0$

3) Strictly complementary constraints. If item $m$ and item n, the two items must be on or not at the same time, the constraint equation can be expressed as $x_{m}-x_{n}=0$

\subsection{Solution}

LINGO is a set of software packages mainly used to solve large-scale linear, nonlinear and integer programming problems. Therefore, LINGO can be used to measure and calculate the investment decision-making problems of comprehensive plan management projects based on 0-1 programming.

\section{Analysis}

It is known that the estimated total investment in the distribution network of $A$ area in a certain year is 11.03225 billion yuan. In this section, based on the previously constructed model, the precise distribution of power grid investment projects in area $\mathrm{A}$ in a certain year is selected for analysis.

\section{(1)Basic data of investment projects}

There is a total of 20 projects in area A that require investment. Among them, there are 10 investment projects in category a and investment projects in category $b$ that are precisely allocated for grid operation. The total investment of the project is 50 million yuan. The information of each project is shown in Table 1.
Table 1. Fundamental data table of class a (large industry) investment projects

\begin{tabular}{|c|c|c|c|c|c|c|c|c|c|}
\hline \multicolumn{2}{|c|}{$\begin{array}{c}\text { Item } \\
\text { Numb } \\
\text { er }\end{array}$} & \multicolumn{2}{|c|}{$\begin{array}{c}\text { Initial } \\
\text { Investmen } \\
\mathrm{t} \text { (ten } \\
\text { thousand } \\
\text { yuan) }\end{array}$} & \multicolumn{2}{|c|}{$\begin{array}{l}\text { Net } \\
\text { Present } \\
\text { Value } \\
\text { (ten } \\
\text { thousand } \\
\text { yuan) }\end{array}$} & \multicolumn{2}{|c|}{$\begin{array}{c}\text { Net } \\
\text { Present } \\
\text { Value } \\
\text { Rate }(\%)\end{array}$} & \multicolumn{2}{|c|}{$\begin{array}{l}\text { Comprehensi } \\
\text { ve Cost of } \\
\text { Grid } \\
\text { Operation (ten } \\
\text { thousand } \\
\text { yuan) }\end{array}$} \\
\hline $\mathrm{a}$ & $\mathrm{b}$ & $\mathrm{a}$ & b & $\mathrm{a}$ & $\mathrm{b}$ & $\mathrm{a}$ & $b$ & $\mathrm{a}$ & $\mathrm{b}$ \\
\hline 1 & 11 & 233 & $\begin{array}{c}32 \\
6\end{array}$ & $\begin{array}{c}30 \\
0\end{array}$ & $\begin{array}{c}45 \\
3\end{array}$ & $\begin{array}{c}1.2 \\
9\end{array}$ & $\begin{array}{c}1 . \\
39\end{array}$ & 7.2 & 10.8 \\
\hline 2 & 12 & 500 & $\begin{array}{c}14 \\
0\end{array}$ & $\begin{array}{c}61 \\
2\end{array}$ & $\begin{array}{c}21 \\
5\end{array}$ & $\begin{array}{c}1.2 \\
2\end{array}$ & $\begin{array}{c}1 . \\
54\end{array}$ & 17.4 & 7.8 \\
\hline 3 & 13 & 120 & $\begin{array}{c}16 \\
0\end{array}$ & $\begin{array}{c}15 \\
0\end{array}$ & $\begin{array}{c}30 \\
1\end{array}$ & $\begin{array}{c}1.2 \\
5\end{array}$ & $\begin{array}{l}1 . \\
88\end{array}$ & 4.5 & 7.6 \\
\hline 4 & 14 & 148 & $\begin{array}{c}21 \\
1\end{array}$ & $\begin{array}{c}22 \\
0\end{array}$ & $\begin{array}{c}35 \\
7\end{array}$ & $\begin{array}{c}1.4 \\
9\end{array}$ & $\begin{array}{l}1 . \\
69\end{array}$ & 4.9 & 8.4 \\
\hline 5 & 15 & 320 & $\begin{array}{c}22 \\
3 \\
\end{array}$ & $\begin{array}{c}42 \\
0 \\
\end{array}$ & $\begin{array}{c}33 \\
5 \\
\end{array}$ & $\begin{array}{c}1.3 \\
1 \\
\end{array}$ & $\begin{array}{l}1 . \\
50\end{array}$ & 14.9 & 6.3 \\
\hline 6 & 16 & 300 & $\begin{array}{c}41 \\
1\end{array}$ & $\begin{array}{c}32 \\
5\end{array}$ & $\begin{array}{c}52 \\
3\end{array}$ & $\begin{array}{c}1.0 \\
8\end{array}$ & $\begin{array}{c}1 . \\
27\end{array}$ & 5.6 & 11.6 \\
\hline 7 & 17 & 195 & $\begin{array}{c}35 \\
0\end{array}$ & $\begin{array}{c}22 \\
0\end{array}$ & $\begin{array}{c}36 \\
9\end{array}$ & $\begin{array}{c}1.1 \\
3\end{array}$ & $\begin{array}{l}1 . \\
05\end{array}$ & 7.8 & 7.3 \\
\hline 8 & 18 & 280 & $\begin{array}{c}26 \\
5\end{array}$ & $\begin{array}{c}31 \\
1\end{array}$ & $\begin{array}{c}30 \\
5\end{array}$ & $\begin{array}{c}1.1 \\
1\end{array}$ & $\begin{array}{c}1 . \\
15\end{array}$ & 7.3 & 5.2 \\
\hline 9 & 19 & 450 & $\begin{array}{c}22 \\
8\end{array}$ & $\begin{array}{c}72 \\
1\end{array}$ & $\begin{array}{c}24 \\
5\end{array}$ & $\begin{array}{c}1.6 \\
0\end{array}$ & $\begin{array}{l}1 . \\
07\end{array}$ & 14.4 & 3.95 \\
\hline $\begin{array}{l}1 \\
0\end{array}$ & 20 & 311 & $\begin{array}{c}11 \\
0\end{array}$ & $\begin{array}{c}41 \\
9\end{array}$ & $\begin{array}{c}25 \\
4\end{array}$ & $\begin{array}{c}1.3 \\
5\end{array}$ & $\begin{array}{c}2 . \\
31\end{array}$ & 12.8 & 4.9 \\
\hline
\end{tabular}

(2)Optimal Algorithm for Investment Decision of Distribution Network Project

The total investment in the region in 2019 is 50 million yuan. The net present value rate and the comprehensive cost of the power grid are selected as the decision value. According to the model established in the previous article, the objective function of the investment project is expressed as follows.

$$
\begin{aligned}
& \max N P V R=\sum_{i=1}^{20}\left(N P V R_{i} \times X_{\mathrm{i}}\right) \\
& \min C_{j o \text { int }}=\sum_{i=1}^{20}\left(C_{j o \text { int }-i} \times X_{i}\right)
\end{aligned}
$$

Table 2. Constraints for different types of projects

\begin{tabular}{|c|c|c|c|c|}
\hline $\begin{array}{c}\text { Total } \\
\text { Investment } \\
\text { (ten } \\
\text { thousand } \\
\text { yuan) }\end{array}$ & Type & $\begin{array}{c}\text { Investme } \\
\text { nt } \\
\text { Allocatio } \\
\text { n Ratio }\end{array}$ & $\begin{array}{c}\text { Maximum } \\
\text { Investment } \\
\text { Amount (ten } \\
\text { thousand } \\
\text { yuan) }\end{array}$ & $\begin{array}{c}\text { Association } \\
\text { Constraint }\end{array}$ \\
\hline \multirow{2}{*}{5000} & $\mathrm{~A}$ & $35 \%$ & 1750 & $\mathrm{x} 7-\mathrm{x} 9=0$ \\
\cline { 2 - 5 } & $\mathrm{B}$ & $65 \%$ & 3250 & $\begin{array}{c}\mathrm{x} 14-\mathrm{x} 17 \leqslant \\
0\end{array}$ \\
\hline
\end{tabular}

(3)Optimal Algorithm Process for Investment Decision of Distribution Network Project 


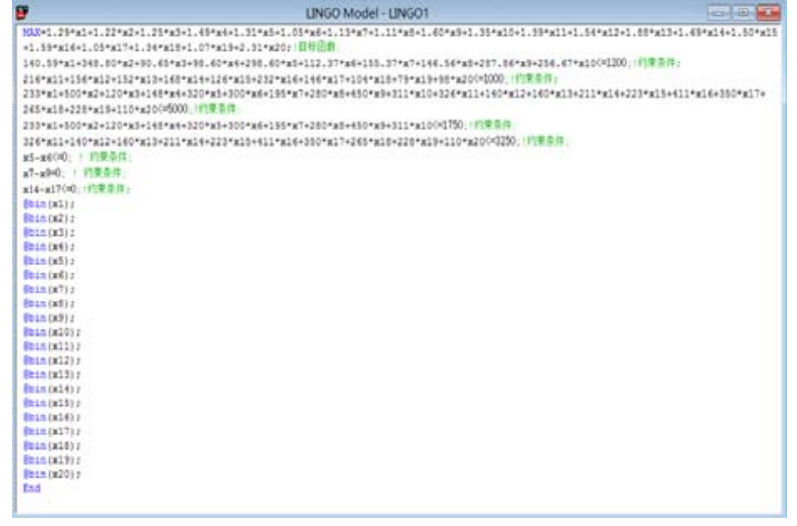

Fig. 2. Diagram of optimization program for investment decision of distribution network project

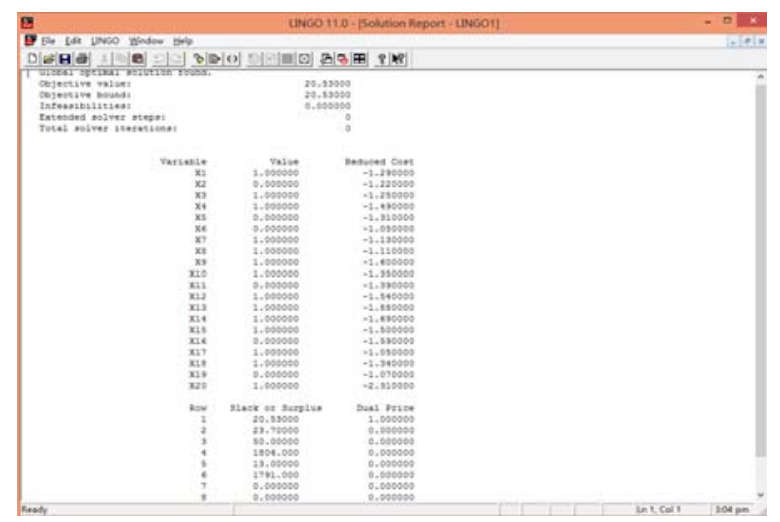

Fig. 3. Diagram of optimization result of investment decision of distribution network project

After the objective function and constraint conditions are established, LINGO is used to solve the model. The calculation results are shown in Table 3 .

Table 3. Optimal result of power grid project investment decision

\begin{tabular}{|c|c|c|}
\hline \multicolumn{2}{|c|}{ Calculation Content } & Result \\
\hline \multirow{3}{*}{ Type } & $\mathrm{A}$ & $\begin{array}{c}1,3,4,7,8, \\
9,10\end{array}$ \\
\cline { 2 - 3 } & $\mathrm{B}$ & $\begin{array}{c}12,13,14, \\
15,17,18,20\end{array}$ \\
\hline \multirow{2}{*}{ Total Investment (ten thousand yuan) } & 3196 \\
\hline \multicolumn{2}{|c|}{ Balance Investment (ten thousand yuan) } & 1804 \\
\hline
\end{tabular}

It can be seen from the above results that after the investment is completed, the project decision value is 20.53. Due to the constraints of the entire investment project, the balance of funds after the completion of the investment is 18.04 million yuan, of which the unselected projects are 2,5,6,11,16 and 19. So the second optimization should be done for the unselected projects.

The second optimization result is that projects $2,5,11,16$ and 19 can be invested, and the risk of the investment amount increases by 1174.4 yuan. Therefore, the calculation results of the matching algorithm between the investment project and the weak link of the power grid is shown in Table 4:
Table 4. Two calculation results of matching algorithm between investment project and weak link of power grid

\begin{tabular}{|c|c|c|c|c|c|c|}
\hline $\begin{array}{l}\text { Ty } \\
\text { pe }\end{array}$ & $\begin{array}{l}\text { Result } \\
\text { (Not } \\
\text { select } \\
\text { ed) }\end{array}$ & $\begin{array}{c}\text { Planne } \\
\mathrm{d} \\
\text { invest } \\
\text { ment } \\
\text { allocat } \\
\text { ion } \\
\text { ratio }\end{array}$ & $\begin{array}{l}\text { Planne } \\
\text { d } \\
\text { Invest } \\
\text { ment } \\
\text { (ten } \\
\text { thousa } \\
\text { nd } \\
\text { yuan) }\end{array}$ & $\begin{array}{c}\text { Actual } \\
\text { Invest } \\
\text { ment } \\
\text { Alloca } \\
\text { tion } \\
\text { Ratio }\end{array}$ & $\begin{array}{c}\text { Actual } \\
\text { Invest } \\
\text { ment } \\
\text { (ten } \\
\text { thousa } \\
\text { nd } \\
\text { yuan) }\end{array}$ & $\begin{array}{l}\text { Balanc } \\
\text { e } \\
\text { Invest } \\
\text { ment } \\
\text { (ten } \\
\text { thousa } \\
\text { nd } \\
\text { yuan) }\end{array}$ \\
\hline A & $2,5,6$ & $35 \%$ & 1750 & $\begin{array}{c}54.35 \\
\% \\
\end{array}$ & 1737 & \multirow{2}{*}{1804} \\
\hline B & $\begin{array}{c}11,16 \\
19\end{array}$ & $65 \%$ & 3250 & $\begin{array}{c}45.68 \\
\% \\
\end{array}$ & 1459 & \\
\hline A & 6 & $35 \%$ & 1750 & $\begin{array}{c}51.14 \\
\%\end{array}$ & 2557 & \multirow[b]{2}{*}{19} \\
\hline B & / & $65 \%$ & 3250 & $\begin{array}{c}48.48 \\
\%\end{array}$ & 2424 & \\
\hline
\end{tabular}

It can be seen from the above results that when the investment is optimized for the first time, under the constraint of ensuring that the risk cost is within a certain range, projects $2,5,6,11,16$, and 19 are not selected, and the investment balance is 18.04 million yuan; when it comes to the second optimization investment, the entire investment is completed, and in order to meet the investment objectives and constraints, the final result of the two types of projects is to exclude project 6 without investment, and the remaining projects are invested. This investment increases the risk cost of 11.744 million yuan. However, the net present value rate of the entire project is maximized, with a balance of only 190,000 yuan. The investment aiming to solve the weak links of the power grid should be based on ensuring safety, so the investment should be made according to the first optimization results, but if you want to maximize the allocation of resources as much as possible, you can appropriately increase the investment.

\section{Conclusion}

Based on the objective functions such as the largest net present value rate, the smallest grid risk value, and the investment ratio and other constraints, this paper constructs a distribution network investment decisionmaking optimization model. The case is calculated and analyzed, and the investment results are obtained. Under the premise of meeting certain safety benefits, the economic benefits of distribution network investment are maximized. This model can provide theoretical guidance for investment in regional power grids and even large power grid projects.

\section{Acknowledgments}

This work is supported by Research on Big Data Correlation Analysis of Key Nodes in Distribution Network Engineering Project Management (SGTYHT/18-JS-209) 


\section{References}

1. Tang Yafang. Optimal model of distribution network investment decision based on annual expected maximum return[J]. Power Grid and Clean Energy, 2015, 031(009):6-11.

2. Niu D, Song Z, Wang M , et al. Improved TOPSIS method for power distribution network investment decision-making based on benefit evaluation indicator system $[\mathrm{J}]$. International Journal of Energy Sector Management, 2017, 11(4):595-608.

3. Cui Wenting, Liu Hong, Yang Weihong, et al. Research on investment distribution and project optimization in distribution network[J]. China Electric Power, 2015, 48(11):149-154.

4. Zhou Xiaomin, Zhang Quan, Yang Weihong, et al. Optimization of medium-voltage distribution network projects based on the marginal reliability of reliability[J]. Power Grid and Clean Energy, 2017, 033(005):24-30,39. 